\title{
Antioxidants Therapy
}

National Cancer Institute

\section{Source}

National Cancer Institute. Antioxidants Therapy. NCI Thesaurus. Code C67025.

Treatment with antioxidants in order to protect cells against damage caused by oxygenfree radicals. 